\title{
Hydrogen production with sea water electrolysis using Norwegian offshore wind energy potentials
}

\author{
Techno-economic assessment for an offshore-based hydrogen production approach \\ with state-of-the-art technology
}

\author{
Konrad Meier
}

Received: 4 February 2014/ Accepted: 10 April 2014/Published online: 13 May 2014

(C) The Author(s) 2014. This article is published with open access at Springerlink.com

\begin{abstract}
This study looks into possibilities of hydrogen production on an offshore platform in Norway, to capitalize Norway's offshore wind potential matching political goals to reduce emissions and make Norway's transportation sector cleaner. The potential power output of a hypothetical offshore wind farm has been assessed using real operating data of other wind farms. The usable electricity was between $258 \frac{\mathrm{GWh}}{\text { year }}$ and $404 \frac{\mathrm{GWh}}{\text { year }}$ segmented into three scenarios. Solid oxide electrolysis cell and proton exchange membrane electrolysis are compared. Their function and the necessary technologies to operate them are described in detail. Based on these scenarios the annual hydrogen production was calculated with values between 1530 and 8020 tons per year. The second part of the study estimates the investment to find the production cost per kilogram hydrogen, which was compared to recent fuel prices in Norway to see whether the production of hydrogen was profitable. Prices vary between $5.20 €$ and $106.10 €$ per $\mathrm{kg}$ hydrogen.
\end{abstract}

Keywords Offshore wind - Hydrogen - Electrolysis . PEM · SOEC · Norway

\section{Introduction}

Human caused emission of greenhouse gases (GHG), mostly by the use of fossil fuels for energy production and transportation is a widely agreed cause of recent climate change [1].

K. Meier $(\bowtie)$

Stuttgart University of Applied Sciences, CMR Prototech, Bergen, Norway

e-mail: konradmeier@gmail.com
Norway plans to cut GHG emissions down to 15.2 million tons of $\mathrm{CO}_{2}$ equivalent till 2020 and achieve carbon neutrality by 2050 [2]. The present electricity production in Norway is around $95 \%$ renewable (mainly hydropower), thus Norway has to look out for alternatives to reduce GHG emissions. Transportation must supply a substantial proportion to emission cuts [3].

To reduce emission in transportation the changeover to clean fuels such as electricity or hydrogen from renewable energy is necessary. Norway is putting effort into establishing hydrogen as a transportation fuel by offering tax exemptions and incentives for fuel cell vehicles [4]. Norway already has a pioneering role in hydrogen production [5].

The hydrogen economy is widely discussed by researchers but remains so far a hypothetical solution to the world's future energy and transportation fuel supply. Today's hydrogen production is used mostly for ammonia production and oil refinery processes [6].

If hydrogen is to become a main driver of future energy storage and transport, the consequence is that the scale of hydrogen production has to increase immensely [7]. This study looks into large-scale hydrogen production in Norway as an option to supply the country's transportation with clean fuel and to enhance Norway's leading role in a future hydrogen economy.

The majority of today's hydrogen production shown in Table 1 is based on fossil resources such as natural gas, oil and coal [8] which consequently cannot be seen as a clean energy carrier or transportation fuel as GHG emissions emerge during the production. There are many approaches to the production of hydrogen, water electrolysis being one of the most basic [7]. Hydrogen production from water electrolysis needs only water and electricity as input. It is emission free as long as renewable energy is used. 
Table 1 World hydrogen production and technologies

\begin{tabular}{lr}
\hline World hydrogen production (in $\left.\mathrm{bn} \mathrm{Nm}^{3} / \mathrm{a}\right)[9,10]$ & \\
\hline Direct production & 190 \\
Steam methane reforming & 120 \\
Partial heavy oil oxidation & 310 \\
Subtotal & \\
Production as byproduct & 90 \\
Gasoline reforming & 33 \\
Ethylene production & 7 \\
Other, chemical industry & 50 \\
Chlorine-alkali electrolysis & 50 \\
Coal gasification & 190 \\
Subtotal & 500 \\
Total & \\
Equal to 44,923 Million tons ( 50 Million in 2012) &
\end{tabular}

Considering peak oil, the limitation of fossil resources [11] and climate change, water electrolysis is a very promising technology [12] for future hydrogen production.

Norway has big wind energy resources that are currently marginally capitalized because the remaining potential of hydropower is sufficient and more likely to be developed to satisfy future energy demands [3].

Developing offshore wind energy in Norway for electricity exports is also not an option, as demand exceeding wind energy is causing problems to the European power grid and developing wind energy on a large scale requires better transmission and distribution grid infrastructure [13, 14].

In Norway the best wind resources are offshore or at the coast, where only weak developed power grid exists [15].

Utilizing Norway's offshore wind energy to produce hydrogen off- or close to shore could develop a hydrogen production economy in Norway, opening a perspective to exploit wind resources while matching Norway's political goals of reducing GHG emissions at the same time.

\section{Objectives}

This study delivers a first appraisal of the technology and economics of a large-scale offshore hydrogen production platform with electrolysis using offshore wind energy. Most of the described technologies are mature, but are put into a new context.

The technical assessment drawing on existing research and own calculations will illustrate possible scenarios for offshore-based hydrogen production with state-of-the-art technologies. Based on this the annual hydrogen production and efficiency will be determined and the specific energy demand will be expressed in the form of $\frac{\mathrm{kWh}}{\mathrm{kg}}$.
In the economical assessment the main outcome is specified as costs per $\mathrm{kg}$ hydrogen $\left(\frac{\epsilon}{\mathrm{kg}}\right)$ based on the estimated annual production and an estimation of the annual cost for the proposed hydrogen production plant.

Both the technological and the economical assessments will be described in a range of scenarios to offer more realistic results, as many references have shown specific costs for the production of hydrogen from electrolysis in a range from $0.36 €^{1}$ to above $20 €$ per $\mathrm{kg}$ depending on the chosen parameters [16-19].

Implications and the needs for future development will be argued in the concluding discussion.

\section{Limitations}

The outcomes in price and efficiency are very sensitive to whether optimistic or pessimistic scenarios are chosen. Since there is currently no large-scale demand for hydrogen for transportation, this has to be considered for any further steps taken. However, this study only examines the side of production of hydrogen with a main focus on electrolysis. Other technological challenges (such as desalination) will be included but simplified so that the need of further research is shown and a first appraisal considering all technological parts can be given.

The results can offer suggestive evidence and information on whether this kind of large-scale hydrogen production is possible and should be seen as a first concept of how it could be approached. All results from own calculations are shown with a maximum of two fractional digits; other numbers are shown as quoted and used in other publications.

\section{Literature review and state-of-the-art}

The concept of hydrogen production from electricity summarized under the term "power-to-gas" is not new, including various concepts of producing hydrogen from wind energy. Different concepts and projects are described in $[8,15,16,19-21]$.

Decentralized hydrogen production facilities are likely to be placed at fuel stations. These plants would be grid connected and could be used as grid-stabilizing facilities.

All grid-connected concepts are more likely to be implemented where intermittent renewable energy is already largely in place to store excess electricity and stabilize the grid.

Grid connection is state-of-the-art but also costly and a major cause of conversion and transmission losses.

\footnotetext{
${ }^{1}$ Not from renewable energy [15].
} 
However, most "wind-to-gas" concepts refer to grid-connected wind farms. Considering the size of such plants to match Norway's theoretical demand of hydrogen as a transportation fuel which is 450,000 tons, over 1,200 of the largest today produced electrolysers and over 4 billion liters of water per year would be needed.

Large areas would be necessary to build these plants onshore which could be compensated with offshore sited hydrogen production, using freely available sea water.

Furthermore, using offshore wind reservoirs solely to produce hydrogen could be a solution to make offshore wind energy exploitable in Norway. It would exclude the costs of grid connection and problems caused to the grid due to intermittency, and improve the acceptance of wind energy in the society due to these problems.

But at the same time new challenges related to producing hydrogen offshore arise, for example hydrogen transportation to shore and new technological requirements.

A 100 megawatt (MW) wind farm will constitute the baseline of this study.

Technical assessment of offshore hydrogen production

In this section, the technical necessities of offshore-based hydrogen production will be described. The most feasible cases will be selected based on median values of literature review.

A base case as the most realistic scenario will be created between best and worst case scenarios. Based on this, the yearly produced amount of hydrogen for each scenario will be calculated, as well as the specific energy demand and the efficiency.

\section{Wind farm}

The electric energy supply of this study will come from a $100 \mathrm{MW}$ offshore wind park. The overall potential for exploitable offshore-generated electricity in Norway is estimated between 18 and 45 TWh per year. This number is based on a study provided by the Norwegian Water Resources and Energy Directorate that proposes 15 locations for offshore wind farms with magnitudes between 100 and $2000 \mathrm{MW}$ [22].

As wind farms are usually developed over time, it is practicable to use a simple number as a base case. Mathur et al. have shown that the capacity of $100 \mathrm{MW}$ represents the minimum capacity for economically feasible hydrogen production using offshore wind [23].

Distance from the shore is included as a cost factor in the economical assessment.

The area selected is close to the German offshore wind farm alpha-ventus, based on which operating data an output

\section{Energy production in Norway}

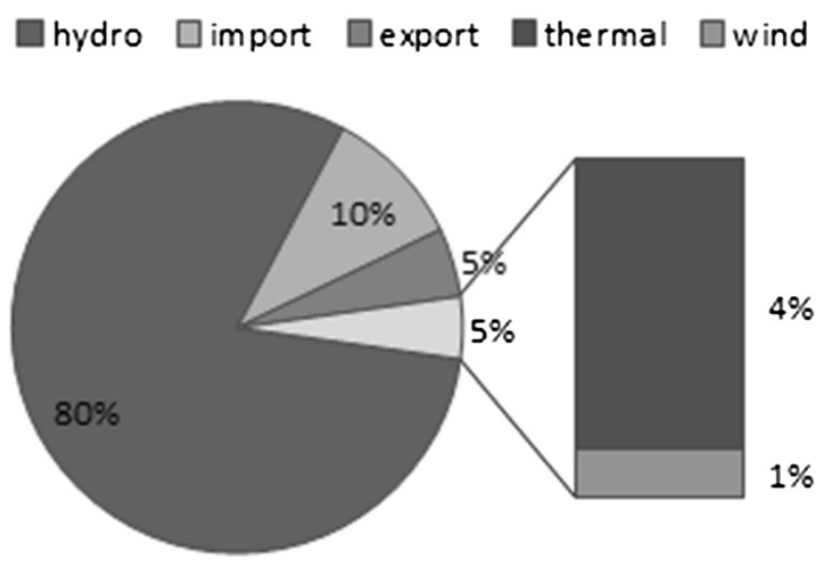

Fig. 1 Electricity in Norway [24]

profile was created $[25]^{2}$ and extrapolated to the capacity profile of a $100 \mathrm{MW}$ wind farm (Figs. 1, 2).

In discussion with CMR Prototech engineers and their technology manager [26] it has been agreed that a minimum of $5 \%$ of the installed capacity is necessary for a stable system. Therefore, only power produced above $5 \%$ of the installed capacity is taken into account. However, sufficient production is available throughout $75 \%$ of the year.

Figure 3 shows the output profile of alpha-ventus for a full year of production.

Taking all electricity above $5 \%$ of the installed capacity into account adds up to $257.72 \frac{\mathrm{GWh}}{\text { year }}$. This will be taken as the worst case scenario since it is likely that the actual available power is higher because the output of the analyzed offshore farm alpha ventus (60 MW) was $267 \frac{\mathrm{GWh}}{\text { year }}$ in 2011 [27]. In addition, transmission losses of electricity are less when there is no grid connection. As seen in Table 2, full production hours are estimated to $4,050 \mathrm{~h}$ per year which results in total electric power output of $405 \frac{\mathrm{GWh}}{\text { year }}$ and $403.63 \frac{\mathrm{GWh}}{\text { year }}$ of usable electricity extrapolated to the capacity profile and excluding power under $5 \%$. This is taken as a best-case scenario.

For the base case, the arithmetic mean between the worst and best-case values is taken and extrapolated to the output profile. This adds up to $331.68 \frac{\mathrm{GWh}}{\text { year }}$.

\footnotetext{
$\overline{2}$ http://www.alpha-ventus.de/index.php?id=101; [20] provides $15 \mathrm{~min}$ values of real time fed-in offshore wind power and alpha ventus was the only operating farm for the selected time according to [64]. Detailed offshore wind data for Norway was not available.

From 15 min values for 1 year operating time of the $60 \mathrm{MW}$ wind farm alpha ventus a daily capacity factor has been calculated. This analysis of production hours was then converted to an output profile of a $100 \mathrm{MW}$ wind farm.
} 
Fig. 2 Norwegian electricity reservoirs $[3,22,28]$

Fig. 3 Output profile of alpha ventus for one year

Table 2 Specification of electrolysis

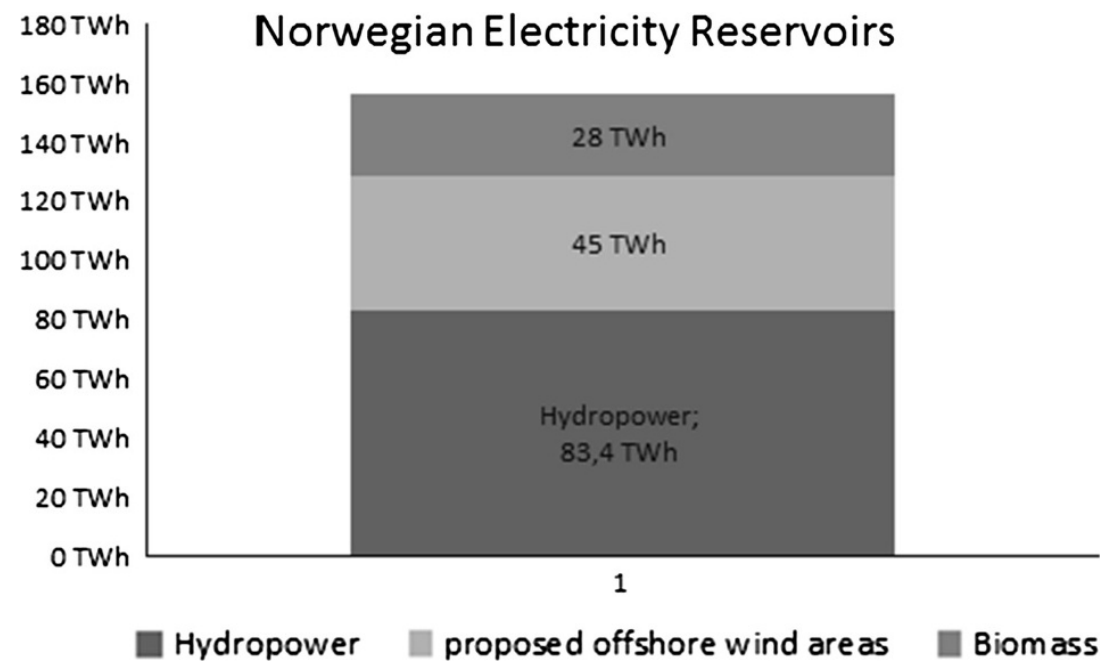

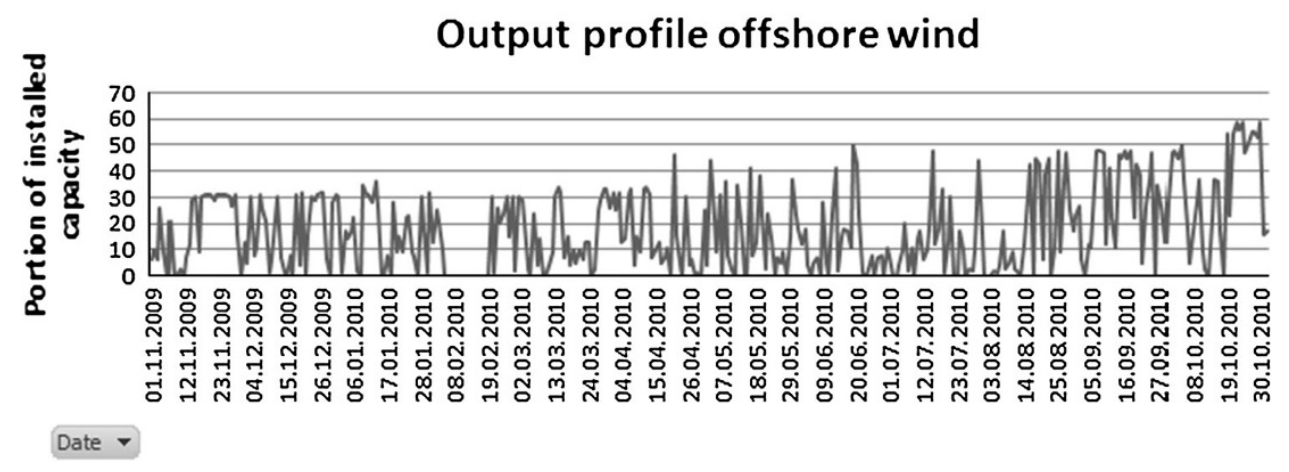

\begin{tabular}{lllll}
\hline \multicolumn{4}{l}{ Specifications of different electrolysis technologies [16, 38-40] } \\
\hline Type & Fuel & Temperature & Main product & Max. realized size \\
\hline Brine & $\mathrm{NaCl}$ : Brine & $90{ }^{\circ} \mathrm{C}$ & $\mathrm{NaOH}+\mathrm{Cl}_{2}$ & N.A. \\
Alkaline & $25 \% \mathrm{KOH}$ : Lye and water & $80{ }^{\circ} \mathrm{C}$ & $\mathrm{H}_{2}$ & $2.5 \mathrm{MW}$ \\
PEMEC & Fresh water & $<100{ }^{\circ} \mathrm{C}$ & $\mathrm{H}_{2}$ & $0.3 \mathrm{MW} ; 3 \mathrm{MW}$ planned \\
SOEC & Steam & $500-1,000{ }^{\circ} \mathrm{C}$ & $\mathrm{H}_{2}$ & $200 \mathrm{~kW}$ (modular) \\
\hline
\end{tabular}

\section{Hydrogen production platform}

The platform where all systems for hydrogen production are based is the main uncertainty in economic terms. However, offshore platforms are state-of-the-art technology. The offshore oil and gas industry builds platforms where sophisticated machinery, such as chemical processing, drilling and other refinery processes as well as living quarters, is placed on the platform [29]. Most offshore wind farms need substations to collect the cables for grid connection and for power transformation and conversion [30, 31]. Offshore platforms are a well-known technology in Norway, where the biggest offshore gas platform Troll A has been built [32, 33]. Therefore, the technical feasibility is given.
Offshore wind output data describes the usable electricity including transformation and transmitting. Transmission losses occur only marginally as electricity is used locally. Li et al. [34] report high efficiencies for electrolyser power converters up to $95 \%$. Therefore, the estimated power output will be seen as the usable power for the system including current converting and transformation.

\section{Electrolyser systems and analysis of electrolysis process}

The electrolyser is the core system which makes it the main element to be examined. There are four principle ways of electrolysis shown in Table 2. 
Table 3 Efficiencies and specifications of electrolysis solutions

\begin{tabular}{|c|c|c|c|c|c|c|c|c|c|}
\hline \multirow{2}{*}{$\begin{array}{l}\text { Electrolyser }[8,15,41-44] \\
\text { Scenario }\end{array}$} & \multicolumn{3}{|l|}{ PEM } & \multicolumn{3}{|l|}{ SOEC } & \multicolumn{3}{|c|}{ Alkaline } \\
\hline & Worst & Base & Best & Worst & Base & Best & Worse & Base & Best \\
\hline Efficiency $(\%)$ & 38.45 & 62.86 & 85.8 & 38.8 & 66.25 & 94.1 & 68.63 & 72.85 & 77.1 \\
\hline Cell voltage (volt) & 2 & 1.74 & 1.48 & 1.48 & 1.29 & 1.1 & 2.2 & 1.95 & 1.7 \\
\hline Pressure (bar) & 13.8 & 21.9 & 30 & 1 & 1 & 1 & 1 & 15.5 & 30 \\
\hline Feed-in & \multicolumn{3}{|c|}{ Fresh water } & \multicolumn{3}{|c|}{ Steam (and hydrogen) } & \multicolumn{3}{|c|}{$\begin{array}{l}\text { Potassium lye }(\mathrm{KOH})- \\
\text { water solution }\end{array}$} \\
\hline Electrode material & \multicolumn{3}{|c|}{$\begin{array}{l}\text { Platinum, iridium, } \\
\text { ruthenium, rhodium, } \\
\text { polymer membrane }\end{array}$} & \multicolumn{3}{|c|}{$\begin{array}{l}\text { Solid oxide ceramic, } \\
\text { e.g.: } \mathrm{Y}_{2} \mathrm{O}_{3}, \mathrm{ZrO}_{2} \text {, } \\
\text { Co- } \mathrm{ZrO}_{2}\end{array}$} & \multicolumn{3}{|c|}{$\begin{array}{l}\text { Nickel, copper, } \\
\text { mangan, wolfram, } \\
\text { ruthenium }\end{array}$} \\
\hline
\end{tabular}

Brine electrolysis would be the most obvious system as it uses a sodium chloride $(\mathrm{NaCl})$ water solution which is basically a form of concentrated sea water [35]. However, there was close to no data found on sea water electrolysis. [36] and [37] stated that due to impurities and the insufficient concentration of $\mathrm{NaCl}$, brine electrolysis is possible but not in the focus of their research. It is, however, a standardized industry process to produce caustic soda with hydrogen as byproduct.

The most common electrolysis process is alkaline electrolysis which uses potassium hydroxide $(\mathrm{KOH})-$ water solution, which would require transport and storage of $\mathrm{KOH}$ and is therefore not considered as feasible either.

The proton exchange membrane electrolysis cell (PEMEC) and the solid oxide electrolysis cell (SOEC) are electrolysis solutions which require only water as feed in. Further analysis will be done for these options. Specifications of the chosen electrolysers are shown in Table 3 in comparison with alkaline electrolysis.

When examining the operation of electrolysers, the characteristics of offshore wind have to be considered. Offshore wind power is highly variable. However, according to the European Wind Energy Association (EWEA) it is not intermittent meaning irregular and unpredictable changes or start/stop intervals in power output on a minute or even second basis do not occur. Short-term variability (within the minute) is not an issue, while variations within the hour are significant [45].

The variability is the crucial factor for the dimensioning of an electrolysis-based hydrogen plant, as it requires electrolysers and auxiliary systems to be able to handle this variation and power converters to deliver the right voltage at different capacities with more or less same efficiency. Grid-connected electrolysis concepts have the advantage that electrolysers can run steadily at the same capacity and run throughout the whole year.

As mentioned in 2.1.1 sufficient electricity (more than $5 \%$ ) is produced $75 \%$ of the time but the power output varies strongly in a range of 5-80\% of the installed capacity. The positive implication is that the wind farm can deliver energy throughout most of the year, so that annual production amounts of hydrogen could be predicted rather safely. Downtime is not so much of an issue as the handling of varying loads.

Siemens has recently introduced a megawatt electrolysis prototype (PEM) that can adapt changes in load within seconds and is able to process three times its nominal capacity for a period of time [38].

The electrolysers analyzed in this study are seen to have a nominal capacity of $50 \%$ of the maximum available power. Change in capacity loads will affect efficiencies to some extent. According to Bartels et al. [19] this affects alkaline and PEM electrolysis most and can lead to dangerous conditions at very low capacities, because gaseous hydrogen and oxygen can evaporate through the membrane and create an explosive environment.

To reduce complexity of this study efficiencies of auxiliary processes are seen as set for each scenario. A factor for the decrease of efficiency due to capacity loads of the electrolyser is introduced as a range of $80-100 \%$ where $50 \%$ of the wind farms capacity is seen as the ideal capacity level of the electrolyser. The decision to take into account only electricity above $5 \%$ of the minimum capacity is also in respect of varying efficiencies at different capacity loads. The ideal level of dimensioning has to be further researched and simulated.

Both chosen electrolysers use water as feed-in stream, but are different in process and specifications. The solid oxide electrolyser (SOEC) needs a steam generator and a high-capacity compressor is necessary as hydrogen is produced at atmospheric pressure. The proton exchange membrane electrolyser (PEM) works pressurized so the compressor for transportation requires less power and the input stream of the PEM electrolyser is fresh water. The SOEC ceramic material requires no noble and rare metals as the PEM, which makes it potentially cheaper.

The basic electrolysis reaction is

$1 \mathrm{H}_{2} \mathrm{O}+$ Electricity $=1 \mathrm{H}_{2}+\frac{1}{2} \mathrm{O}_{2}$

This reaction is endothermic and the required energy by the process is 
$\Delta H=\Delta G+T \Delta S$

where $\Delta H\left(\frac{\mathrm{J}}{\mathrm{mol}}\right)$ is the change of enthalpy, $\Delta G\left(\frac{\mathrm{J}}{\mathrm{mol}}\right)$ is the Gibbs free energy and represents the minimum electrical energy and $T \Delta S\left(\frac{\mathrm{J} \times \mathrm{K}}{\mathrm{mol}}\right)$ is the process temperature and the entropy change and represents the minimum thermal energy demand [41, 46, 47].

$\Delta G$ can compensate the thermal energy demand and a change of temperature can lower the electric energy demand [48].

Based on $\Delta H$ the required cell voltage in the electrolyser can be determined with

$V_{\mathrm{C}}=\frac{\Delta H}{2 \times F}$

where 2 is the number of electrons and $F$ is the Faraday constant which is $F=96,485.3365 \frac{\mathrm{C}}{\mathrm{mol}}$ [49-52]. $\Delta H$ is usually the higher heating value (HHV) of hydrogen. The important difference here is as shown in Table 3 that the SOEC electrolyser can operate at a cell voltage below minimum cell voltage of the higher heating value of hydrogen ${ }^{3}$ which is

$V_{\mathrm{C} \_\mathrm{HHV}}=\frac{141.86\left(\frac{\mathrm{kJ}}{\mathrm{g}}\right) \times M}{2 \times F}=1.4819 \mathrm{~V}$

and in some cases even below the cell voltage of the lower heating value which is

$V_{\mathrm{C} \_ \text {LHV }}=\frac{119.93\left(\frac{\mathrm{kJ}}{\mathrm{g}}\right) \times M}{2 \times F}=1.253 \mathrm{~V}$

where $M=2.015 \frac{\mathrm{g}}{\mathrm{mol}}$ is the molar mass of hydrogen. This shows how the increased temperature influences the energy need of hydrogen production and this is the reason why in theory efficiency above $100 \%$ can be accomplished.

The amount of hydrogen produced can be calculated by

$m_{\mathrm{H} 2}=\frac{P}{V_{\mathrm{C}} \times 2 \times F} \times M \times \eta=(\mathrm{kg})$

where $P(\mathrm{MWh})$ is the available energy, $V_{\mathrm{C}}(\mathrm{V})$ is the cell voltage, $F$ is Faraday's constant as introduced above, $M$ is the molar mass of hydrogen and $\eta$ is the electrolyser efficiency.

The overall process efficiency can then be expressed when comparing the specific energy demand in $\frac{\mathrm{kWh}}{\mathrm{kg}}$ to the thermodynamic minimum as referring to the higher heating value of

$39.405 \frac{\mathrm{kWh}}{\mathrm{kg}}$

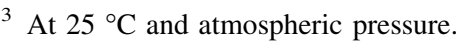

\section{Water treatment}

Both the SOEC and PEM electrolyser cannot be operated directly on sea water but need process water or boiler feed water quality, respectively, with a maximum of $0.5 \mathrm{ppm}$. Total dissolved units (TDS) [53]. Water treatment includes desalination and purification for the PEM and the SOEC and steam generation only for the latter. Desalination processes can be divided into electrical and thermal. Reverse osmosis (electrical) is the most commonly used technology, however, thermal processes such as multi-effect distillation and multistage flash distillation produce better quality and require less post-treatment for demineralization [54-56].

Post-treatment always includes chemical treatment in a resin polishing filter containing chemicals to bind remaining ions and other dissolved solids in the desalinated water. In the desalination process chemicals are also included to prevent scale [55, 57].

Using chemicals is undesirable as changing or refilling of the chemicals is inevitably more difficult on an isolated offshore platform. In the reviewed literature, there was no data available to technically quantify the necessary chemicals and the frequency of refilling. This is one additional challenge of the offshore approach that has to be further investigated.

Calculations done will be made based on the given efficiencies assuming that the whole process is described including the chemical treatment, necessary pumps and further equipment.

Thermal water treatment is the direct logical choice for the SOEC electrolyser since it requires steam. Reverse osmosis is slightly more efficient but it delivers lower quality (400 ppm TDS versus $5 \mathrm{ppm}$ ), and therefore requires more sophisticated post-treatment, which should be avoided. For these reasons thermal desalination will be chosen for both electrolysers, namely multistage flash distillation as it is mentioned for producing boiler feed water quality with $12 \frac{\mathrm{kWh}}{\mathrm{m}^{3}}[54]$ on a temperature range $70-120{ }^{\circ} \mathrm{C}$.

The energy needed can be determined by multiplying the energy need per cubic meter ${ }^{4}$ with the amount of water that is necessary which is

$m_{\dot{H}_{2} \mathrm{O}}=\frac{\dot{m}}{M \times \eta} \times M_{\mathrm{H}_{2} \mathrm{O}}$

where $\dot{m}\left(\frac{\mathrm{kg}}{s}\right)$ is the production rate of hydrogen, $\mathrm{M}$ is the molar mass of hydrogen $\left(2.015 \frac{\mathrm{g}}{\mathrm{mol}}\right), \eta$ is the efficiency of water use and $M_{\mathrm{H}_{2} \mathrm{O}}$ is the molar mass of water $\left(18.015 \frac{\mathrm{g}}{\mathrm{mol}}\right)$.

The PEM electrolyser system is less complex which leaves more electricity for the electrolysis process. The electrolysis itself is slightly less efficient and the main disadvantage is the use of expensive materials such as

\footnotetext{
${ }^{4}$ With $999,975 \mathrm{~kg}$ per $\mathrm{m}^{3}$.
} 
platinum. The distillated and demineralized water proceeds directly into the electrolyser, is split up into hydrogen and oxygen and then hydrogen proceeds into the compressor.

For the SOEC the water is preceded into an electric steam boiler which is state-of-the-art for other industry processes [58] and then conducted into the electrolyser. The energy needed for steam generation can be determined with

$\dot{Q}=\frac{\mathrm{H}_{2} \mathrm{O}_{\min } \times(\Delta h)}{\eta}(\mathrm{MW})$

where $\Delta h$ is the enthalpy change for water between $\sim 100$ ${ }^{\circ} \mathrm{C}$ and the desired temperature and $\eta$ is the boiler efficiency that can be up to $99 \%$ [59-61].

In the SOEC electrolyser there will be also a mass flow of air and some of the produced hydrogen to increase efficiency. To keep the electrolysis cell hot while the wind farm delivers insufficient energy wind power below $5 \%$ can still be used. During zero electricity production times it is assumed that the SOEC system will consume some hydrogen to retain the heat for a faster process start up [26].

Leaving the electrolyser, hydrogen is separated from steam and then inducted into the compressor. In both process designs heat exchangers have been included to show potential of efficiency increase.

The advantages of the SOEC are the availability and price of materials and the increasing efficiency due to the process heat, though the auxiliary equipment also requires more of the energy available. The main disadvantage is the immaturity of the system in comparison to all other electrolyser solutions and the need of steam and a highcapacity compressor which makes the process design more complex $[62,63]$.

\section{Compression and transportation of produced hydrogen}

One main difference between the SOEC and the PEM electrolyser is that the SOEC operates at atmospheric pressure while the PEM electrolyser operates pressurized and is in some systems described to substitute a compressor completely.

The energy of compression can be calculated with

$W=\frac{n \times R \times T \times \ln \left(\frac{p_{2}}{p_{1}}\right)}{\eta}(\mathrm{W})$

where $n$ is the molar amount of hydrogen, $R=$ $8.314\left(\frac{\mathrm{J}}{\mathrm{mol} \times \mathrm{K}}\right)$ is the universal gas constant, $\ln \left(\frac{p_{2}}{p_{1}}\right)$ is the logarithm of the ratio of pressure after and before compression and $\eta$ is the compressor efficiency. Compressor efficiency is around $70 \%$ [64]. Handling different amounts of hydrogen due to variable capacity loads will reduce efficiency especially for the SOEC system. Therefore, efficiency of $50 \%$ is used.

For the proposed $100 \mathrm{MW}$ system it could be more feasible to transport the hydrogen by ship. Pipelines are a standard solution to transport gas from offshore platforms and are the only choice when the proposed project is scaled up. Subsea pipelines can also be used to deliver hydrogen to other countries as done in the case of natural gas [29].

Pipeline pressure is between 25 and 300 bar in different sources $[29,65,66]$. For simplification the selected pressure is $100 \mathrm{bar}$.

Economical assessment of offshore hydrogen production

The objective of the economical assessment is to see what price per kg of hydrogen for the proposed system will be.

Reviewed literature shows that costs of all components are proposed in a range of specific costs, e.g., $\left(\frac{€}{\mathrm{~kW}}\right)$ or $\left(\frac{\epsilon}{\mathrm{m}^{3}}\right)$. The values from different studies are applied for three scenarios. Based on the maximum capacity of the components the total investment cost can be estimated.

Price ranges are consistent for most components. The main uncertainty is the platform cost. The estimation for this will be based on the values for platform cost of a wind farm presented in the offshore wind assessment for Norway [67] and compared to the costs of offshore oil rigs to see if the picture is realistic. The price ranges of electrolysers vary strongly between $16,250\left(\frac{€}{\mathrm{~kW}}\right)$ [20] and $350\left(\frac{€}{\mathrm{~kW}}\right)$ [39]. These varying costs have been put into three more realistically moderate-ranged scenarios.

Based on the collected data for all the components of the system the total investment and the annual costs have been estimated using the comparative cost method. The selected cost ranges of the different components for each scenario are presented in Table 4 and based on literature review from [20-23, 33, 34, 39, 43, 54, 65, 67-73].

The wind cost can be modified to the specifications of the proposed system. According to [67] electrical equipment, substation and grid connection adds up to $20 \%$ of the wind investment cost. These components of the wind farm are unneeded for this system. Therefore, $20 \%$ has been subtracted from the wind farm investment. Green and Vasilakos [68] present a table by the European Environment Agency (EEA) with multiplying factors to adjust the cost to water depth and distance from shore. These have been added to the calculation to simulate different distances from shore. The $20 \%$ basis has been used to estimate the platform and electrical equipment price. For this it was estimated that the platform will be 2.5 times the size and therefore 2.5 times the investment cost of $20 \%$ of the 
Table 4 Price range of components

\begin{tabular}{|c|c|c|c|c|}
\hline Component & Unit & $\begin{array}{l}\text { Best } \\
\text { case }\end{array}$ & Base case & $\begin{array}{l}\text { Worst } \\
\text { case }\end{array}$ \\
\hline Interest rate & & $7 \%$ & $10 \%$ & $12 \%$ \\
\hline $\begin{array}{l}\text { Lifetime } \\
\quad \text { (Electrolyser) }\end{array}$ & Years & 10 & 10 & 10 \\
\hline Lifetime (other) & Years & 25 & 20 & 15 \\
\hline Platform & $M €$ & 56.9 & 114.05 & 171.2 \\
\hline Wind & $\left(\frac{\epsilon}{\mathrm{kW}}\right)$ & 1,137 & 2,281 & 3,424 \\
\hline Electrolysis & & 2,810 & 4,253 & 7,062 \\
\hline Steam generation & & $1,215^{\mathrm{a}}$ & $1,215^{\mathrm{a}}$ & $1,215^{\mathrm{a}}$ \\
\hline Desalination $^{\mathrm{a}}$ & $\left(\frac{€}{m^{3} / d}\right)$ & & 1,450 & \\
\hline Pipeline $^{a}$ & $\frac{k \epsilon}{\mathrm{km}}$ & & 474.3 & \\
\hline Length & $\mathrm{km}$ & 50 & 125 & 200 \\
\hline $\mathrm{O} \& \mathrm{M}^{\mathrm{a}}$ & & & $\begin{array}{l}2 \% \text { of total } \\
\text { annual cost }\end{array}$ & \\
\hline
\end{tabular}

a Simplified

wind farm total investment. This adds up to a widely spread price range. Costs for oil rigs are in a similarly wide range [74]. The pipeline costs have been added to the scenario with different distances to clarify the influence of transportation cost. The final annual costs have been carried out with and without transportation.

Figure 4 shows the influence on the total investment for each component of the system. The major cost component in both systems is the wind farm. The total investment in the base case is $716.15 \mathrm{M} €$ for the PEM System and $640.85 \mathrm{M} €$ for the SOEC system which is about $12 \%$ less. This is mainly due to the influence of the size of the electrolyser and because auxiliary equipment is inexpensive when compared to wind farm and electrolyser. The implication is that even though the SOEC system needs a far more sophisticated overall system with steam generation and more powered compression, its total cost could be lowered.

The potential demand of hydrogen for Norwegian domestic transportation is 450,000 tons per year [17, 75]. Over 100 times the proposed systems size would be necessary to produce this amount of hydrogen.

With an average fuel consumption of 7.5 Liters per $100 \mathrm{~km} \mathrm{[76]} \mathrm{and} \mathrm{an} \mathrm{average} \mathrm{fuel} \mathrm{price} \mathrm{of} 2.07 €(15.65$ NOK) [77] per Liter, hydrogen produced as transportation fuel would be profitable if it can be produced on specific costs below

$7.5 \times 2.07 €=\frac{15.53 €}{\mathrm{~kg} \mathrm{H}_{2}}$

The present price of hydrogen in Norway per $\mathrm{kg}$ is $11.83 €$ according to [5].

\section{Results}

Results of the technical assessment

Based on the equations given in "Technical assessment of offshore hydrogen production" the power output variations by the wind farm, the total production of hydrogen per year were calculated for each described scenario.

Using an iterative approach including all the auxiliary systems, the available wind power and the electrolyser itself has determined that the auxiliary equipment of the SOEC electrolyser will consume about $35 \%$ of the total available energy, which is partly compensated by higher efficiency. In the same iterative approach it was assessed that the auxiliary equipment for the PEM electrolyser will consume about $3 \%$ of the total available power.

The outcomes of the main scenarios are shown in Table 5.

The PEM electrolyser produces more hydrogen in any chosen scenario, due to the lower energy consumption of its auxiliary systems. However, the efficiency of the SOEC process itself is much higher. In the best-case scenario, the overall efficiency is almost the same and the amount of produced hydrogen is similar. When comparing the specific energy demand with the thermodynamic minimum of $39.405 \mathrm{kWh}$ the efficiency of the total process is between 76.67 and $23 \%$.

\section{Results of the economic assessment}

The price per kg hydrogen was estimated based on the annual production of hydrogen and annual cost of the system according to the comparative cost method. The results are presented in Table 6 .

The significant finding is that the specific costs vary strongly depending on the chosen scenarios but that even excluding transportation the production cost per $\mathrm{kg}$ hydrogen is currently too high to be profitable with both assessed systems.

On the other hand, the base-case scenarios are not too far away from the price equivalent of fuel for transportation with the SOEC system slightly in favor, the best-case scenarios are profitable.

All parameters have a strong influence on the profitability and have to be carefully chosen and assessed when further conceptualizing a project to produce hydrogen on a large scale.

What should also be considered is that fuel prices are likely to rise in the future which will influence the breakeven point for hydrogen production. Selecting the basecase results including transport this would mean that a price per liter of gasoline of $3.13 €$ for the PEM system or $2.92 €$ for the SOEC system would be price equivalent to 
Fig. 4 Cost components influence on total investment (base case)

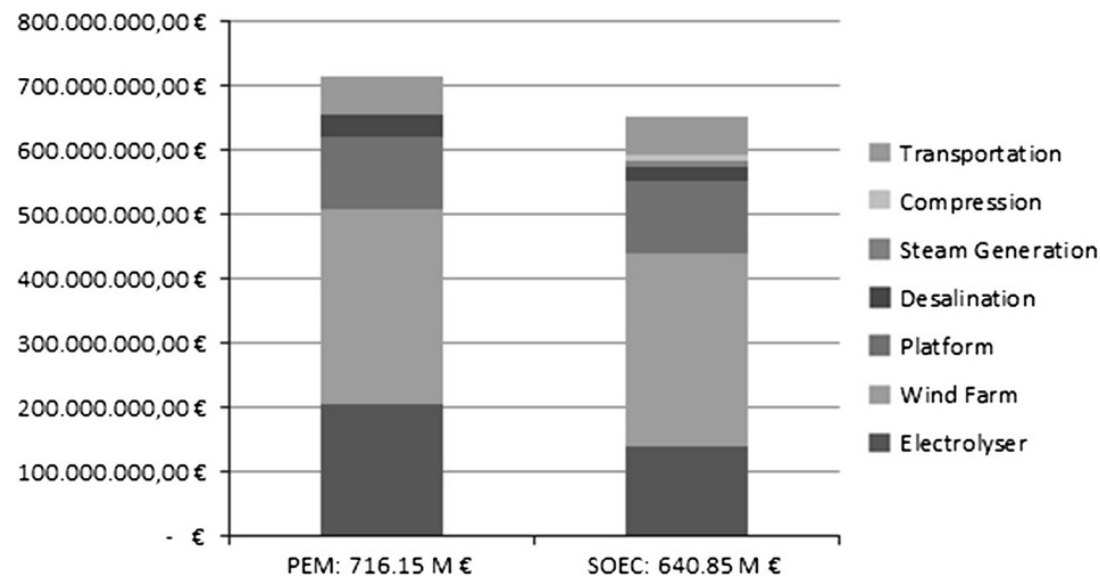

Table 5 Hydrogen production and efficiencies for different scenarios and electrolysers

\begin{tabular}{|c|c|c|c|c|c|c|c|}
\hline \multirow[t]{2}{*}{ Scenario } & \multirow[t]{2}{*}{ Unit } & \multicolumn{3}{|l|}{ PEM } & \multicolumn{3}{|l|}{ SOEC } \\
\hline & & Worst & Base & Best & Worst & Base & Best \\
\hline Hydrogen produced & $\mathrm{kg}$ & $1,709,494$ & $4,105,517$ & $8,023,902$ & $1,533,458$ & $3,893,751$ & $7,903,266$ \\
\hline $\begin{array}{l}\text { Energy demand of } \\
\text { electrolysis }\end{array}$ & $\frac{\mathrm{kWh}}{\mathrm{kg}}$ & 150.5 & 80.05 & 49.85 & 111.38 & 56.28 & 33.81 \\
\hline $\begin{array}{l}\text { Overall specific energy } \\
\text { demand }\end{array}$ & $\frac{\mathrm{kWh}}{\mathrm{kg}}$ & 155.2 & 82.53 & 51.39 & 171.35 & 86.59 & 52.02 \\
\hline Total efficiency & $\%$ & 25.39 & 47.75 & 76.68 & 23 & 45.51 & 75.75 \\
\hline
\end{tabular}

Table 6 Price per kilogram hydrogen

\begin{tabular}{lrrrrrrrr}
\hline$\left(\frac{\epsilon}{\mathrm{kg}}\right)$ & \multicolumn{1}{c}{ PEM } & & & & SOEC & & \\
\cline { 2 - 3 } & Worst & Base & Best & & Worst & Base & Best \\
\hline Incl. transport & 106.10 & 23.44 & 6.30 & & 106.15 & 21.84 & 5.17 \\
Excl. transport & 86.71 & 20.61 & 6.02 & & 84.33 & 18.85 & 4.89 \\
\hline
\end{tabular}

the production cost of hydrogen. Gasoline prices rising above this would slowly put hydrogen produced in the described way in a profitable situation.

Various studies forecast cost reduction for offshore wind with further expansion of offshore wind in Europe and worldwide [69], and also cost reduction for electrolysers when they are being built on a large scale [19].

The electrolyser technologies described are rather immature and further development also bares the potential of cost reduction.

However, this means that both a change in fuel prices in Norway as well as a positive development in wind farm and electrolyser costs can create a profitable scenario for offshore-based hydrogen production.

Another important factor is the research and simulation of the ideal power level of the electrolyser in combination with varying wind output as this can decrease the maximum size but also influence its life time and therefore can influence the investment cost as well.
Apart from the not given profitability a significant finding is that large-scale hydrogen production on an offshore platform is technically feasible and could be economically feasible if the prices of the components decrease and efficiency of the technology increases.

With average efficiency of electrolysers, using the total offshore wind potential of Norway of 300 TWh would produce approximately 680,000 tons per year which would cover Norway's complete potential hydrogen demand for transportation. This means that there is the theoretical potential to exploit Norway's offshore wind reserves for hydrogen production to fit future hydrogen demands in Norway and perhaps even for export purposes to maintain Norway's status as a major fuel exporting country.

\section{Concluding discussion}

The study has described a large-scale offshore electrolysis system. The annual production of hydrogen and the production price per kilogram hydrogen have been assessed. The overall result of the study is that with state-of-the-art technology it is possible to build large-scale hydrogen production platforms, but with the current prices for the system components and comparing the price with present fuel equivalent prices, the production of hydrogen offshore is not profitable. 
Two different advancing electrolysis technologies have been compared to see the potential of these technologies.

The main advantage of the SOEC system, which is the use of freely available heat from another process cannot meet its full potential within the offshore system. However, it is comparable in hydrogen production and in favor when it comes to production cost. The auxiliary systems are far more complex, which makes careful system design necessary to increase overall efficiencies, for example using waste heat recovery where possible.

For the offshore-based approach, seawater brine electrolysis would be a promising choice if it can handle the impurities or if water treatment technologies advance to produce usable water with less cost and increased efficiency. The main products of brine electrolysis are part of the chemicals used for water treatment in desalination plants. This could potentially be a solution to produce more hydrogen while increasing the systems functionality by providing water purification and demineralization processes with their necessary mass flows, perhaps also by combining different electrolysis technologies on a platform. The assessments done should be further investigated and ideally simulated. The treatment of sea water and use of treated water should be further assessed and tested in laboratory conditions to quantify the need of chemicals for purification.

Other fields for further research lie in the power production and conversion. Wind turbines produce alternating current. Usually, it is converted to high voltage direct current and transmitted to shore where it has to be converted to alternating current again to feed it into the grid. Electrolysers need low voltage direct current, so if wind farms produced direct current some of the electrical equipments could be replaced which would reduce cost and conversion losses.

The question of building production plants centralized offshore or decentralized onshore is rather in advantage of decentralized production because grid-connected systems are easier to operate, hydrogen transportation will be unnecessary and building on land is less expensive than offshore. On the other hand, the size of the necessary systems to cover the complete demand might put centralized solutions, either on- or offshore, in favor.

The results of the study can be seen as suggestive evidence for concept development of offshore-based hydrogen production and further research planning.

Looking at a future worldwide hydrogen economy using hydrogen as transportation fuel and energy storage, the decisive factor for Norway will be if the future offers a large and stable European power grid, or if a European hydrogen infrastructure and market emerges. A European power grid with developed storage technologies could make it profitable to just exploit wind resources for electricity exports.
If it was profitable to sell hydrogen to other countries, Norway could also fortify its unique position as a clean energy country and fuel exporter and become Europe's largest clean fuel exporter.

Acknowledgments The idea to produce this study came from and was financially supported by CMR Prototech AS, Bergen, Norway. The company did not influence the results in any way.

Open Access This article is distributed under the terms of the Creative Commons Attribution License which permits any use, distribution, and reproduction in any medium, provided the original author(s) and the source are credited.

\section{References}

1. US Environment Protection Agency: http://www.epa.gov. http:// www.epa.gov/climatechange/basics/\#responsible (2012). Accessed 19 Mar 2013

2. Statistics Norway: http://www.ssb.no Statistisk sentralbyra. http:// www.ssb.no/en/natur-og-miljo/statistikker/klimagassn/aar-forelopi ge/2013-05-07?fane=tabell\&sort=nummer\&tabell=111404 (2013). Accessed 9 May 2013

3. Fuel Cell Today: fuel cells and hydrogen in Norway. http://www.fue lcelltoday.com/analysis/surveys/2013/fuel-cells-and-hydrogen-innorway (2013). Accessed 27 Feb 2013

4. The Norwegian Electric Vehicle Association: http://www.elbil.no Norsk Elbilforening. http://www.elbil.no/om-lbilforeningen/eng lish-please (2012). Accessed 19 Mar 2013

5. The Norwegian Hydrogen Council: http://www.hydrogen.no. http:// www.hydrogen.no/assets/files/Hydrogenradet/Handlingsplan/Nasjo nal_handlingsplan_ENG_web_enkeltsidig.pdf (2012). Accessed 19 Mar 2013

6. Steinberger-Wilckens, R., Trümper, S.: http://www.ika.rwthaachen.de. http://www.ika.rwth-aachen.de/r2h/index.php/European Hydrogen_Infrastructure_and_Production\#Part_II:_Industrial_sur plus_hydrogen_and_markets_and_production (2007). Accessed 19 Mar 2013

7. Dincer, I.: Green methods for hydrogen production. Int. J. Hydrogen Energy 37, 1954-1971 (2011)

8. Gahleitner, G.: Hydrogen from renewable electricity: an international review of power-to-gas pilot plants for stationary applications. Int. J. Hydrogen Energy 38, 2039-2061 (2012)

9. Evers, A., Fair, P.R.: http://www.hydrogenambassadors.com. http:// www.hydrogenambassadors.com/background/worldwide-hydrogenproduction-analysis.php (2001). Accessed 19 Mar 2013

10. Geitmann, S.: http://www.hydrogeit.de—der Wasserstoff-Guide. http://www.hydrogeit.de/wasserstoff.htm (1999). Accessed 19 Mar 2013

11. Evans, C., Elam, C., Robert, J.: Overview of hydrogen production. National Renewable Energy Laboratory, CO (2004)

12. FreedomCAR and Fuel Partnership: Hydrogen productionoverview of technology options. http://www1.eere.energy.gov/ hydrogenandfuelcells/pdfs/h2_production_roadmap.pdf (2009). Accessed 8 May 2013

13. The European Wind Energy Association: Powering Europe: wind energy and the electricity grid. http://www.ewea.org/fileadmin/e wea_documents/documents/publications/reports/Grids_Report_2010. pdf (2010). Accessed 20 Mar 2013

14. Andresen, T., Bauerova, L.: http://www.bloomberg.com BLOO MBERG L.P. http://www.bloomberg.com/news/2012-10-25/wind mills-overload-east-europe-s-grid-risking-blackout-energy.html (2012). Accessed 20 Mar 2013 
15. Greiner, C., Korpas, M., Holen, A.: A Norwegian case study on the production of hydrogen from wind power. Int. J. Hydrogen Energy 32, 1500-1507 (2006)

16. Ivy, J.: Summary of electrolytic hydrogen production-milestone completion report. http://www.nrel.gov/hydrogen/pdfs/ 36734.pdf (2004). Accessed 22 Apr 2013

17. Norwegian Hydrogen Forum: http://www.hydrogen.no/om-hyd rogen/ofte-stilte-sporsmal (2013). Accessed 5 Mar 2013

18. Linneman, J., Steinberger-Wilckens, R.: Realistic costs of windhydrogen vehicle fuel production. Int. J. Hydrogen Energy 32, 1492-1499 (2006)

19. Bartels, J., Pate, M., Olson, N.: An economic survey of hydrogen production from conventional and alternative energy sources. Int. J. Hydrogen Energy 35, 8371-8384 (2010)

20. Menanteau, P., Quéméré, M., Le Duigou, A., Le Bastard, S.: An economic analysis of the production of hydrogen from windgenerated electricity for use in transport applications. Energy Policy 39, 2957-2965 (2011)

21. Prince-Richard, S., Whale, M., Djilali, N.: Techno-economic analysis of decentralized hydrogen production for fuel cell vehicles. Int. J. Hydrogen Energy 30, 1159-1179 (2005)

22. Norwegian Water Resources and Energy Directorate. http://www.nve. no/Global/Publikasjoner/Publikasjoner\%202010/Havvind_ENG_K3. pdf (2010). Accessed $20 \mathrm{Feb} 2013$

23. Mathur, J., Agarwal, N., Swaroop, R., Shah, N.: Economics of producing hydrogen as transportation fuel using offshore wind energy systems. Energy Policy 36, 1212-1222 (2008)

24. Statistics Norway: http://www.ssb.no statistisk sentralbyra. http:// www.ssb.no/en/energi-og-industri/nokkeltall (2010). Accessed 19 Mar 2013

25. TenneT TSO GmbH: http://www.tennettso.de. http://www.tenne ttso.de/site/en/Transparency/publications/network-figures/actualand-forecast-wind-energy-feed-in (2013). Accessed 4 Apr 2013

26. Wærnhus, I.: (ivar.warnhus@prototech.no) Feb-Apr 2013. Hydrogen production based on PEM or SOEC electrolysis. Various E-mails to Meier, K., (konradmeier@gmail.com)

27. Deutsche Offshore-Testfeld und Infrastruktur GmbH \& Co. KG: http://www.alpha-ventus.de. http://www.alpha-ventus.de/indexph p?id=101 (2013). Accessed 9 Apr 2013

28. European Environment Agency: Europe's onshore and offshore wind energy potential. An assessment of environmental and economic constraints. European Environment Agency, Copenhagen (2009)

29. Statoil: http://www.statoil.com. http://www.statoil.com/en/OurOpe rations/ExplorationProd/ncs/Njord/Pages/default.aspx (2007). Accessed 9 Apr 2013

30. European Wind Energy Association: http://www.wind-energy-thefacts.org/—electrical system. http://www.wind-energy-the-factsorg/e n/part-i-technology/chapter-5-offshore/wind-farm-design-offshore/e lectrical-system.html. Accessed 9 Apr 2013

31. Offshore Windenergy Europe: http://www.offshorewindenergy.org . http://www.offshorewindenergy.org/ca-owee/indexpages/down loads/CA-OWEE_Technology.pdf (2008). Accessed 9 Apr 2013

32. National oceanic and atmospheric administration, Types of offshore platforms, "http://www.oceanexplorer.noaa.gov," National oceanic and atmospheric administration, [Online]. Available: http://www.oceanexplorer.noaa.gov/explorations/06mexico/bac kground/oil/media/types_600.html. Accessed 9 Apr 2013

33. Statoil: http://www.goodideas.statoil.com. http://www.goodideas. statoil.com/gas-machine\#/gas-machine. Accessed 9 Apr 2013

34. Li, C.-H., Zhu, X.-J., Cao, G.-Y., Sui, S., Hu, M.-R.: Dynamic modeling and sizing optimization of stand-alone photovoltaic systems using hybrid energy storage systems. Renew Energy 34, 815-826 (2008)

35. El-Bassuoni, A., Sheffield, S., Veziroglu, T.: Hydrogen and fresh water production from sea water. Int. J. Hydrogen Energy 7, 919-923 (1982)
36. Hollmann, K.: (karsten.hollmann@thyssenkrupp.com). Electrolysis with sea water (2013). E-mail to Meier, K. (konradmeier@gmail. com)

37. Hauser, S.: (Stefan.Hauser@ cac-chem.de) Elektrolysen auf Basis von Meerwasser (2013). E-mail to Meier, K. (konradmeier@gmail.com)

38. Buck, C.: http://www.siemens.com Siemens. http://www.sieme ns.com/innovation/apps/pof_microsite/_pof-spring-2012/_html_e n/electrolysis.html (2012). Accessed 12 Apr 2013

39. Manage, M., Hodgson, D., Milligan, N., Simons, S., Brett, D.: A techno-economic appraisal of hydrogen generation and the case for solid oxide electrolyser cells. Int. J. Hydrogen Energy 36, 5782-5796 (2011)

40. sunfire GmbH: http://www.sunfire.de. http://www.sunfire.de. Accessed 15 Apr 2013

41. Ferrero, D., Lanzini, A., Santarelli, M., Leone, P.: A comparative assessment on hydrogen production from low- and high-temperature electrolysis. Int. J. Hydrogen Energy 38, 3523-3536 (2013)

42. Bicáková, O., Straka, P.: Production of hydrogen from renewable resources and it's effectiveness. Int. J. Hydrogen Energy 37, 11536-11578 (2012)

43. Korpas, M., Greiner, C.: Opportunities for hydrogen production in connection with wind power in weak grids. Renew. Energy 33, 1199-1208 (2007)

44. Zhang, H., Lin, G., Chen, J.: Evaluation and calculation on the efficiency of a water electrolysis system for hydrogen production. Int. J. Hydrogen Energy 35, 10851-10858 (2010)

45. European Wind Energy Association: http://www.wind-energythe-facts.org-variability. http://www.wind-energy-the-facts. org/en/part-2-grid-integration/chapter-2-wind-power-variability-a nd-impacts-on-power-systems/understanding-variable-output-cha racteristics-of-wind-power-variability-and-predictability.html. Accessed 4 Apr 2013

46. Millet, P., Mbemba, N., Grigoriev, S., Fateev, V., Aukauloo, A., Etiévant, C.: Electrochemical performances of PEM water electrolysis cells and perspectives. Int. J. Hydrogen Energy 36, 4134-4142 (2011)

47. Ganley, J.: High temperature and pressure alkaline electrolysis. Int. J. Hydrogen Energy 34, 3604-3611 (2009)

48. Wang, Z., Mori, M., Araki, T.: Steam electrolysis performance of intermediate-temperature solid oxide electrolysis cell and efficiency of hydrogen production system at $300 \mathrm{Nm}^{3} / \mathrm{h}$. Int. J. Hydrogen Energy 35, 4451-4458 (2010)

49. Gökcek, M.: Hydrogen generation from small-scale wind powered electrolysis system in different power matching modes. Int. J. Hydrogen Energy 35, 10050-10059 (2010)

50. US Department of Energy - Energy Efficiency and RenewablesTechnology Validation: http://www.eere.energy.gov. http:// www1.eere.energy.gov/hydrogenandfuelcells/tech_validation/pdf s/fcm01r0.pdf (2012). Accessed 12 April 2013

51. National Institute of Standards and Technology. http://www. webbook.nist.gov. http://www.webbook.nist.gov/cgi/cbook.cg i?Name=hydrogen\&Units=SI. Accessed 16 Mar 2013

52. Standard Reference Database-National Institute of Standards and Technologies. http://www.physics.nist.gov. http://www.ph ysics.nist.gov/cuu/Constants/index.html. Accessed 14 Mar 2013

53. Ophir, A., Gendel, A.: Adaptation of the multi-effect distillation (MED) process to yield high purity distillate for utilities, refineries and chemical industry. Desalination 98, 383-390 (1994)

54. Ghaffour, N., Missimer, T., Amy, G.: Technical review and evaluation of the economics of water desalination: current and future challenges for better water supply sustainability. Desalination 309, 197-207 (2012)

55. Tewari, P., Prabhakar, S., Ramani, M.: Evaluation of thermal desalination and reverse osmosis for the production of boiler feed water from sea water for coastal thermal power stations in India. Desalination 79, 85-93 (1990) 
56. Khawajia, A., Kutubkhanaha, I., Wieb, J.: Advances in seawater desalination technologies. Desalination 22, 47-69 (2008)

57. Temstet, C., Canton, G., Laborid, J., Durantd, A.: A large high performance MED plant in Sicily. Desalination 105, 109-114 (1996)

58. Wallace, W., Spielvogel, L.: Boilers, field performance of steam and hot water electric boilers. In: Industrial and commercial power systems and electronic space heating and air conditioning joint technical conference, Detroit (1974)

59. AMELIN Group: http://www.amelin.ru. http://www.amelin.ru/e n/catalogue/75/2917/ (2013). Accessed 21 Apr 2013

60. Sussman Boilers: http://www.sussmanboilers.com/. http://www. sussmanboilers.com/ (2008). Accessed 5 May 2013

61. Electro-Steam Generator Corp: http://www.electrosteam.com/. http://www.electrosteam.com/ (2010). Accessed 5 May 2013

62. Petipas, F., Qingxi, F., Brisse, A., Bouallou, C.: Transient operation of a solid oxide electrolysis cell. Int. J. Hydrogen Energy 38, 2957-2964 (2013)

63. Shin, Y., Park, W., Chang, J., Park, J.: Evaluation of the high temperature electrolysis of steam to produce hydrogen. Int. J. Hydrogen Energy 32, 1486-1491 (2007)

64. Allen, A.: Efficiency and performance measurements of a PDC Inc. single stage diaphragm hydrogen compressor. http://www.h umboldt-dspace.calstate.edu/bitstream/handle/2148/514/Allen_ thesis_final.pdf? sequence=1 (2008). Accessed 21 Apr 2013

65. Liu, E.: Large scale wind hydrogen systems. http://www1.eere.e nergy.gov/hydrogenandfuelcells/wkshp_wind_hydro.html (2003). Accessed 4 Mar 2013

66. Töpler, J.: http://www.storhy.net StorHy (hydrogen storage systems for automotive application). http://www.storhy.net/train-in/ PDF-TI/03_StorHy-Train-IN-Session-1_3_JToepler.pdf (2006). Accessed 21 Apr 2013

67. Douglas-Westwood: http://www.nve.no-Norwegian Water Resources and Energy Directorate. http://www.nve.no/Global/ Energi/Havvind/Vedlegg/Annet/Offshore\%20Wind\%20Asessment \%20For\%20Norway\%20-\%20Final\%20Report\%20-\%201905 10\%20with\%20dc.pdf (2010). Accessed 20 Feb 2013
68. Green, R., Vasilakos, N.: The economics of offshore wind. Energy Policy 39, 496-502 (2011)

69. The Crown Estate: http://www.thecrownestate.co.uk-offshore wind cost reduction pathways. http://www.thecrownestate.co.uk/ media/305094/Offshore\%20wind\%20cost\%20reduction\%20path ways\%20study.pdf (2012). Accessed 23 Apr 2013

70. Kamal, I.: Integration of seawater desalination with power generation. Desalination 180, 217-229 (2005)

71. Aguado, M., Ayerbe, E., Azcárate, C., Blanco, R., Garde, F., Mallor, R., Rivas, D.: Economical assessment of a wind-hydrogen energy system using WindHyGen Software. Int. J. Hydrogen Energy 34, 2845-2854 (2009)

72. Levitt, A., Kempton, W., Smith, A., Musial, W., Firestone, J. Pricing offshore wind power. Energy Policy 39, 6408-6421 (2011)

73. Zoulias, E., Lymberopoulos, N.: Techno-economic analysis of the integration of hydrogen energy technologies in renewable energy-based stand alone power systems. Renew. Energy 32, 680-696 (2007)

74. Kaiser, M., Snyder, B.: Reviewing rig construction cost factors. Int. J. Energy Environ. Eng. 5, 104 (2014). http://www.offshoremag.com/articles/print/volume-72/issue-7/rig-report/reviewing-rigconstruction-cost-factors.html. Accessed 8 May 2013

75. Deutscher Wasserstoff Verband: H2-ROADMAP-Prinzipielle Anforderungen an die Infrastruktur. DWV Deutscher Wasserstoff Verband e.V., Berlin (2003)

76. Umweltbundesamt: http://www.umweltbundesamt-daten-zurumwelt.de. http://www.umweltbundesamt-daten-zur-umwelt.de/ umweltdaten/public/document/downloadImage.do;jsessionid=B1F E5A8B5F8DDED4612E111C15FDF04D?ident $=24158 \quad$ (2011/ 2012). Accessed 20 Mar 2013

77. Randall, T.: http://www.bloomberg.com Bloomberg L.P. http:// www.bloomberg.com/slideshow/2012-08-13/highest-cheapest-ga s-prices-by-country.html\#slide2 (2012). Accessed 20 Mar 2013 